\title{
Técnicas del contencioso administrativo que refuerzan el principio de legalidad
}

\section{Contentious-administrative techniques that reinforce the rule of law}

Pedro Harris Moya*"-

La lectura sistemática de las disposiciones del contencioso administrativo se manifiesta en las técnicas empleadas en contra de la Administración. Éstas permiten mostrar cómo ciertas prácticas favorecen la impugnación de los actos administrativos, reforzando así el principio de legalidad.

Palabras clave: contencioso administrativo, acto administrativo, principio de legalidad.
The techniques used against the Administration are the consequence of the systematic reading of administrative provisions. These techniques indicate that certain practices are favorable to the judicial review of administrative acts, thus reinforcing the rule of law.

Keywords: administrative litigation, administrative act, rule of law.

\section{Introducción}

La amplitud de la garantía constitucional para acceder al contencioso administrativo (art. 38 inc. $2^{\circ}$ de la Constitución) ${ }^{1}$ no parece conciliable con las limitaciones legales que su desarrollo presenta. Detrás de cada consagración legal favorable a la apertura de recursos contenciosos en este ámbito ${ }^{2}$, suelen encontrarse diferentes restricciones. Los ejemplos de ello

\footnotetext{
* Profesor de Derecho administrativo, Universidad Autónoma de Chile, Santiago, Chile. Dirección postal: Av. Pedro de Valdivia N 641, Providencia, Santiago de Chile. Correo electrónico: pedro.harris@uautonoma.cl.

† Doctor en Derecho público, Universidad de París 1, Panthéon-Sorbonne, Francia.

Artículo recibido el 13 de enero de 2020 y aceptado el 25 de mayo de 2020.

1 Pierry 2000, 11 y ss.; Bermúdez 2010, 108; Pantoja 2010, 695 y ss.; Ferrada 2013, 177.

2 La calificación de acción es preferida para aludir a los mecanismos jurisdiccionales dirigidos en contra del acto administrativo -v.gr.: FerRAdA 2011, 253-. No obstante, esta asimilación no es completa, ya que olvida a la excepción, como una vía de impugnación. Asimismo, la calificación de ciertos "recursos", como el de protección, permiten la fami-
} 
son variados. Desde la inimpugnabilidad de los actos trámite, hasta la expiración del plazo para anular el acto terminal. Desde las limitaciones para producir una condena de actuación, hasta el control de las ejecuciones ${ }^{3}$.

No obstante, la primacía constitucional no solo supone mecanismos derogatorios frente a la contradicción de normas, sino también interpretativos. Estos requieren que ante dos sentidos y alcances diversos de las reglas en oposición, el intérprete opte por la que mayor conformidad constitucional presenta. Si la garantía de acceso al juez posee un valor constitucional en nuestro ordenamiento, entonces sus limitaciones legales deben ser interpretadas restrictivamente ${ }^{4}$, lo que exige no solo considerar un análisis aislado de las disposiciones, sino también su lectura sistemática.

La lectura sistemática de las disposiciones sobre la impugnación administrativa se relacionará con las técnicas contenciosas. Ellas se insertan en un proceso jurisdiccional, a través de prácticas que permiten articular las herramientas que el contencioso administrativo proporciona. Éstas pueden emplearse por el demandante o el demandado pues, como se verá, la presunción de legalidad, de imperio y exigibilidad del acto administrativo (art. 3 inc. final de la Ley $N^{\circ} 19.880$ ) no impide que el administrado pueda adoptar ambos roles, en defensa de la legalidad.

La amalgama del proceso civil y el administrativo, en nuestro ordenamiento, parece explicar la carencia de estudios sobre estos aspectos por parte de la doctrina publicista. Esta explicación, sin embargo, no resulta coherente con las características del proceso administrativo. Pese las reglas comunes al CPC, el proceso administrativo consagra particularidades que lo alejan de él, relacionadas tanto con su valor constitucional, como con al trasvase de instituciones propias del procedimiento administrativo ${ }^{5}$. Un aspecto y otro conforman hoy un proceso con rasgos distintivos.

Uno de los rasgos distintivos del proceso administrativo consiste en diferenciar las formas bajo las cuales la Administración puede provocar una

\footnotetext{
liaridad del término. Por último, la propia ley suele preferir una terminología diversa, como la "reclamación", véase: CARMONA 2005, 207.

3 Teóricamente, dichas restricciones podrían permitir conciliar las exigencias constitucionales de la legalidad, favorable a la apertura irrestricta del contencioso administrativo, y de la seguridad, que requiere de su limitación. En la práctica, sin embargo, no es necesario ir lejos para observar que la ausencia de coherencia y la falta de sistematicidad de las disposiciones que permiten alcanzar este objetivo pueden también suponer una restricción a la seguridad y, lógicamente, también a la legalidad.

${ }^{4}$ La necesidad de esta interpretación restrictiva se justifica, aún más, por la valoración de la impugnabilidad, estructurada bajo la forma de un principio común a las leyes de bases: art. 15 de la Ley $N^{\circ} 19.880$, de 2003, y art. 10 de la Ley $N^{\circ}$ 18.575, de 1986.

5 La Ley $N^{\circ}$ 19.880, de 2003, ha tenido una influencia determinante en la configuración del proceso administrativo. No obstante ello, dicha influencia se explica, en gran medida, por la dificultad de diferenciar su naturaleza del procedimiento administrativo. De hecho, esta dificultad se observa también en el sentido inverso. En rigor, tampoco es "sencillo extrapolar las exigencias procesales imperantes en el ámbito jurisdiccional al terreno propiamente administrativo": VALDIVIA Y BLAKE 2015, 119.
} 
ilegalidad invalidante. La extensión del art. 38 inc. $2^{\circ}$ de la Constitución requiere que esta dimensión conserve una lectura amplia, susceptible de impedir todo vacío de control. Es por esto que las impugnaciones no solo se asocian a una intervención formal, sino también material. Todo ello requiere diferenciar la impugnación de actos (I) y actuaciones (II) de la Administración, al reflejar dos formas de comportamientos lato sensu.

\section{Las técnicas favorables a la impugnación del acto administrativo}

La extensión de la definición de acto administrativo bien pudo servir de base para admitir en nuestro ordenamiento una regla general favorable a su impugnabilidad. En efecto, esta extensión está presente en la noción legal de acto administrativo (que comprende, no solo las decisiones en sentido estricto, sino también los actos desprovistos de contenido decisorio ${ }^{6}$ ) y, por cierto, en el propio ámbito de aplicación de la Ley $N^{\circ} 19.880$ (art. 2), cuyo alcance permite en rigor limitar la opción del legislador de definir tales actos "para efectos de esta ley"7 en concreto ${ }^{8}$.

No obstante, diferentes restricciones convierten a la impugnabilidad en una verdadera excepción. Se trata de limitaciones que no solo operan de manera explícita, sino también implícita o tácitamente. Basta destacar que la asociación del acto administrativo a su procedimiento permite constatarlo, con independencia de la fase de tramitación. Sin perjuicio de las restricciones legales a la impugnación de actos trámite (1), la jurisprudencia ha limitado la impugnación de actos terminales (2). Una situación y otra, sin embargo, permiten ampliaciones indirectas.

\section{La impugnación del acto trámite}

"Todo el procedimiento administrativo está destinado a que la Administración dicte un acto decisorio que se pronuncie sobre la cuestión de fondo y en el cual exprese su voluntad" (art. 8 de la Ley $N^{\circ}$ 19.880). Esta es la razón por la cual el procedimiento es definido como "una sucesión de actos trámite vinculados entre sí (...) que tiene por finalidad producir un acto administrativo terminal" (art. 18 de la Ley $N^{\circ}$ 19.880). La finalidad de "producir"9 tal acto es considerada de manera prioritaria. La sola enumeración de los principios del procedimiento lo demuestra ${ }^{10}$.

La impugnación del acto administrativo supone por ello distinguir aquellos dictados durante la tramitación del procedimiento de aquellos que lo fi-

\footnotetext{
6 Art. 3 inc. $6^{\circ}$ de la Ley $N^{\circ} 19.880$, de 2003.

7 Art. 3 inc. $2^{\circ}$ de la Ley $N^{\circ} 19.880$, de 2003.

8 PieRry 2005, 71 y ss.

9 Bocksang 2010, 236: "El problema de fondo que habría de plantearse es el de si la emisión del acto decisorio es suficiente para que el procedimiento administrativo cumpla el fin que le es propio, que es el de la actualización de la potencia administrativa".

10 Véase los principios de celeridad, conclusivo, economía procedimental y no formalización (arts. 7, 8, 9 y 13 de la Ley $N^{\circ} 19.880$, de 2003).
} 
nalizan. Si bien ambos son actos de la Administración, solo los segundos son directamente impugnables en los términos de la Ley $N^{\circ} 19.880$, Bases de los Procedimientos Administrativos. En efecto, pese a ser mayoritarios en cuanto a su número, los actos trámite únicamente son impugnables en circunstancias de excepción. Aunque esto limita en gran medida los efectos de la amplitud legal de la noción de acto administrativo $(a)^{11}$, diferentes mecanismos permiten afirmar su impugnación indirecta (b).

\section{a) La limitación literal a la impugnación}

La traducción de la finalidad de producir un acto terminal, en términos de impugnabilidad de los actos administrativos, se manifiesta en las limitaciones a dicha impugnación respecto de aquellos que ponen en movimiento el procedimiento. Se trata de los actos trámite, referidos por la ley de manera implícita al definir el procedimiento administrativo en base a su sucesión ${ }^{12}$. Conforme al art. 15 inc. $2^{\circ}$ de la Ley $N^{\circ} 19.880$, "los actos de mero trámite son impugnables solo cuando determinen la imposibilidad de continuar un procedimiento o produzcan indefensión".

Puede observarse así la distancia con que las diferentes leyes de bases ${ }^{13}$ han interpretado la impugnación de los actos administrativos. Particularmente si se considera, como lo ha observado la doctrina, que esta disposición limita el estándar de control anterior a su entrada en vigor, en aplicación del art. 10 de la Ley $N^{\circ}$ 18.575, conforme al cual "[l]os actos administrativos serán impugnables mediante los recursos que establezca la ley"14. Si bien esta disposición omite una referencia totalizadora (que incorpore "todo acto"), ninguna restricción era afirmada.

La perspectiva sustantiva (de la Ley $\mathrm{N}^{\circ} 18.575$ ) se opone así a la perspectiva procedimental (de la Ley $N^{\circ} 19.880$ ), cuyo objeto es evitar que la interposición de recursos limite la tramitación del procedimiento ${ }^{15}$. La forma de conseguir dicho resultado es clara. Salvo excepciones, la ilegalidad de un acto trámite no es impugnable directamente, sino solo de manera indirecta. Ello deberá ocurrir junto con la impugnación del acto terminal. Por ello, solo la dictación de este último abre la impugnación del primero. En caso que diferentes actos administrativos fueran viciados, o que también lo sea el terminal, todos estos vicios deberán atacarse conjuntamente.

En rigor, el legislador pudo interpretar que un acto trámite no era apto para agraviar, al carecer de efectos externos. La ley parece afirmarlo así al

\footnotetext{
11 Art. 15 inc. $2^{\circ}$ de la Ley $N^{\circ} 19.880$, de 2003.

12 Art. 18 de la Ley $\mathrm{N}^{\circ} 19.880$, de 2003.

13 Ley $N^{\circ} 18.575$, de 1986, y Ley No 19.880, de 2003.

14 Soto Kloss 2015, 85.

15 Esta contradicción se aprecia también en la oposición entre el art. 54 de la Ley N N 19.880, de 2003, que impide el recurso paralelo (administrativo y jurisdiccional), y el art. 10 de la Ley $N^{\circ}$ 18.575, de 1986, conforme al cual la interposición de los recursos administrativos (ya sea de reposición o jerárquico) es "sin perjuicio de las acciones jurisdiccionales a que haya lugar".
} 
disponer que "[l]a Administración Pública no iniciará ninguna actuación material de ejecución de resoluciones que limite derechos de los particulares sin que previamente haya sido adoptada la resolución que le sirva de fundamento jurídico" ${ }^{16}$. Si esta resolución es necesaria, también lo será que el procedimiento sea finalizado. Y si lo es, entonces la Administración deberá dictar un acto terminal, que permita impugnar los actos anteriores.

Sin embargo, la inimpugnabilidad del acto trámite puede acarrear efectos perjudiciales para el administrado. En algunos casos podrán asociarse a aspectos sustantivos. Por ejemplo, si el tiempo que media entre el acto trámite y el terminal permite convalidar el primero, por efecto de una modificación del bloque de la legalidad ${ }^{17}$. En otros múltiples casos dichas consecuencias se asociarán a aspectos procesales. Así, el transcurso del tiempo puede limitar los argumentos en su contra (v.gr.: dada la imposibilidad posterior de acreditar circunstancias presentes con anterioridad).

\section{b) La apertura sistemática de la impugnación}

Si el carácter de base de la ley del procedimiento administrativo supone garantizar un mínimo básico de garantías ${ }^{18}$, entonces las disposiciones que limiten los derechos deben interpretarse restrictivamente. Tal es el caso de la inimpugnabilidad del acto trámite, cuya consagración general opera a partir de esta ley. El alcance de esta limitación requiere verificar otras disposiciones que pueden colisionar con la inimpugnabilidad de dichos actos, y examinar la propia noción de acto trámite, debido a la mayor o menor extensión que puede alcanzar su definición.

La inimpugnabilidad del acto trámite de la Ley $\mathrm{N}^{\circ} 19.880$, a través de recursos administrativos, tiene un efecto limitado. $Y$ es que si bien ella puede ser extendida al recurso jerárquico (debido a que la Ley $N^{\circ} 18.575$ solo lo garantiza "cuando proceda"), no puede limitar el recurso de reposición (interpuesto y resuelto por la autoridad que dicta el acto). Primero, porque este

\footnotetext{
16 Art. 50 de la Ley $N^{\circ} 19.880$, de 2003.

17 La inimpugnabilidad del acto administrativo de trámite debe llevar a interpretar que sus vicios se comunican al acto que finaliza el procedimiento. En rigor, solo este último suele ser considerado por la jurisprudencia. Véase: Sentencia TC Rol N 1849-10 (2011), c. 5: "Que el criterio universalmente aceptado es que, salvo disposición en contrario, los actos administrativos se rigen por la normativa vigente al tiempo de su emisión, de modo que a esa luz debe juzgarse en lo que hace a su validez inicial". Dicha época ha sido también afirmada por la Corte Suprema: Abrego Diamantti con Instituto de Normalización Previsional (2007), c. 16: "[q]ue la retroactividad de la anulación del acto ilegítimo se explica y se basa en la necesidad de eliminarlo a contar de la misma fecha en que él se perfeccionó, justamente, porque los vicios que generan su invalidez se han configurado en esa oportunidad, esto es, se debe tratar de defectos congénitos del acto irregular y que tienen tal entidad que obligan a declarar su ineficacia desde la misma fecha". Ello origina la dificultad de precisar cuál es la época de control del acto trámite, considerando que la impugnación dirigida al acto terminal podrá convalidar su vicio y, en ciertos casos, favorecer la inactividad administrativa en espera del cambio de circunstancias. Véase: Trucco con Dirección General de Aguas (2015).

18 Rojas 2007, 117 y ss.; Vergara 2007, 31 y ss.; Jara 2008, 298.
} 
recurso es asimilable a una petición ${ }^{19}$. Y segundo, ya que la Ley $N^{0} 18.575$ garantiza, también de manera básica, la apertura irrestricta de la reposición, al afirmar que podrá interponerse "siempre"20.

Lo mismo ocurre en relación con otros recursos que se alejan del modelo adoptado por la Ley $N^{\circ} 19.880$, para organizar la impugnación, estructurada en base a la notificación o publicación ${ }^{21}$. En efecto, si bien dichos mecanismos permiten abrir por regla general el contencioso administrativo, puede suceder que dicho contencioso ya se encuentre cerrado a esta época, por una fórmula de cómputo diversa, como ocurre en el caso del recurso de protección, abierto por treinta días, desde que el administrado conoció o debió conocer del acto 22 .

Algo similar sucede en relación con el acto trámite considerado en sí mismo. La Ley $N^{\circ} 19.880$ se estructura en torno a un concepto unitario del procedimiento en tramitación. No obstante, en muchas ocasiones un interesado debe tramitar diferentes procedimientos administrativos paralela o sucesivamente, los que se asocian por la finalidad pretendida por él ${ }^{23}$. Este grado de conexión puede originar confusiones ¿debe interpretarse que ellos

19 Art. $19 \mathrm{~N}^{\circ} 14$ de la Constitución de 1980.
20 Art. 10 de la Ley $\mathrm{N}^{\circ} 18.575$, de 1986.
21 Véase Párrafos $1^{\circ}$ y $2^{\circ}$ del Capítulo III de la Ley $N^{\circ} 19.880$, de 2003.
22 El plazo se cuenta "desde la ejecución del acto o la ocurrencia de la omisión o, según la na22 El plazo se cuenta "desde la ejecución del acto o la ocurrencia de la omisión o, según la na-
turaleza de éstos, desde que se haya tenido noticias o conocimiento cierto de los mismos" $\left(N^{\circ} 1\right.$ del Acta $N^{\circ}$ 94-2015, que establece el auto acordado sobre tramitación y fallo del recurso de protección de las garantías constitucionales). El razonamiento judicial permitiría el paralelismo de recursos administrativos y jurisdiccionales en base al art. 20 de la Constitución, que habilita para interponer el recurso de protección "sin perjuicio de los demás derechos que pueda hacer valer ante la autoridad o los tribunales correspondientes". Salazar Godoy con Fisco (2010), citada en: FerRada 2011, 262. Este autor, sin embargo, critica esta posición. "[N]o parece muy consistente con los objetivos perseguidos por el legislador al disponer la regla del artículo 54 ya citado, con una efectiva protección de los derechos de los particulares y, aún menos, con la utilización eficiente del sistema judicial". Pese a ello, la dificultad de apreciar el cómputo de este plazo tiene larga data. Véase: Soto KLoss 1984, 368.

23 En otras ocasiones, estas conexiones no dependen de la finalidad pretendida por el interesado, sino de la propia regulación legal, que conecta diferentes procedimientos o legislaciones. Por ejemplo, ello se observa cuando la dictación de un acto se condiciona por otro, o bien, cuando un mecanismo de coordinación ha sido establecido. Véase: DelHoste 2001, 199 y ss. En nuestro derecho, la recepción de obras y el otorgamiento de patentes municipales es un ejemplo de lo primero (v.gr.: art. 25 bis de la Ley N 19.300: "Las Direcciones de Obras Municipales no podrán otorgar la recepción definitiva si los proyectos o actividades a los que se refiere el artículo 10 no acreditan haber obtenido una resolución de calificación ambiental favorable"; y art. 83 del Código Sanitario: "Las Municipalidades no podrán otorgar patentes definitivas para la instalación, ampliación o traslado de industrias, sin informe previo de la autoridad sanitaria sobre los efectos que ésta puede ocasionar en el ambiente"). En cambio, algunos instrumentos de gestión ambiental son un ejemplo de lo segundo. Es lo que sucede en el Sistema de Evaluación de Impacto Ambiental, al asociar la tramitación de múltiples permisos. Si bien la mayor parte de ellos suelen ser ambientales (tramitados en base a una legislación ambiental diversa a la de bases del medio ambiente), existen al menos una treintena de permisos no ambientales, que imponen "conectar" legislaciones muy diversas. En todos estos casos, es razonable interpretar que los actos conectados son un "trámite" de otro procedimiento y, por tanto, son impugnables en tanto actos de término del procedimiento específicamente tramitado, por aplicación de su legislación. 
conforman un único procedimiento para efectos de su impugnación, o debe conservarse una impugnabilidad separada? ${ }^{24}$.

Una interpretación literal favorece separar la impugnación de procedimientos asociados en su tramitación. Así se concluye de la propia noción del procedimiento administrativo, definida como "una sucesión de actos trámite vinculados entre sí (...) que tiene por finalidad producir un acto administrativo terminal" 25 . La separación que esta disposición consagra entre el acto trámite y el terminal implica que, de reunir ambas facetas, el acto deberá primar en esta última faz, para efectos de permitir su impugnabilidad. Así ha sido interpretado por la jurisprudencia ${ }^{26}$.

\section{La impugnación del acto terminal}

Una vez finalizado el procedimiento, la Administración deberá dictar un acto administrativo terminal, que le permitirá al administrado atacarlo, en base a aspectos de forma o fondo. Sin embargo, en principio, únicamente podrá hacerlo durante el tiempo de ejercicio de los recursos jurisdiccionales que el derecho positivo le otorga. En efecto, un ejercicio tardío supondrá la extinción de la acción, no pudiendo impugnarse el acto posteriormente, por efecto del tiempo (a). Solo una lectura favorable a la imprescriptibilidad de la excepción permite superar tal límite (b).

\section{a) La prescriptibilidad de la acción}

La nulidad constitucional e imprescriptible, afirmada por largo tiempo en base a los arts. 6 y 7 de la $\mathrm{CPR}^{27}$, ha sido progresivamente limitada, sustancial y procesalmente ${ }^{28}$. La limitación sustancial es doctrinaria, y se basa en cuestionamientos a su campo de aplicación en torno a los vicios del acto 29. La limitación procesal es legislativa y obedece a la consagración de múltiples

\footnotetext{
24 Si bien el concepto de acto separable puede ser útil en la aplicación de ciertas reglas sustantivas, también lo es ante la aplicación de algunas disposiciones procesales, como lo es la impugnación. "Hasta ahora, el campo de aplicación más conocido de esta teoría es el de los procedimientos administrativos contractuales, como la licitación pública": VALDIVIA 2018, 208.

25 Art. 18 de la Ley $N^{\circ} 19.880$, de 2003.

26 Así, en el marco de un procedimiento de evaluación ambiental, pueden ser atacados los actos de derecho urbanístico, antes que el proyecto industrial sea rechazado formalmente por parte de la autoridad ambiental. Véase: CGX Castilla con Seremi de Salud de Copiapó (2010), véase: CORDERO VEGA 2011a, 197-198.

27 Pérsico Paris con Fisco (1997).

28 Bermúdez 2010, 104; Ferrada 2010, 189 y ss.; Soto Kloss 2015, 73 y ss.

29 Conforme a una posición jurisprudencial, la nulidad de derecho público solo alcanzaría a los vicios formales del acto, quedando aquellos sustanciales remitidos al legislador, según los arts. 1462, 1682 y 1683 del Código Civil, en relación a la nulidad absoluta respecto de actos contrarios al Derecho público. Si bien esta posición fue afirmada inicialmente -Camacho con Fisco (2006) y Abrego Diamantti con Instituto de Normalización Previsional (2007), véase: BeRmúdEZ 2008, 273 y ss.; Bermúdez 2010, 103 y ss.-, habría sido abandonada posteriormente -Ovalle Lecaros con Fisco, Servicio Agrícola y Ganadero y Servicio de Vivienda y Urbanismo Metropolitano (2012), véase: Bocksang 2012b, 299 y ss.; Sото KLoss 2015, 73 y ss.-. Hoy, la jurisprudencia parece retomar parcialmente la posición inicial. Véase: CONTARDO 2019, 534.
} 
acciones contenciosas especiales ${ }^{30}$, dotadas de menor eficacia debido a su carácter prescriptible ${ }^{31}$. Todo ello origina un concurso de acciones que debe revolverse a favor de una de ellas.

La primera solución al concurso parte de una interpretación extensiva del art. 7 inc. $3^{\circ}$ de la Constitución. La lectura es extensiva porque se interpreta que esta regla establece un régimen prevalente ${ }^{32}$. El administrado podrá elegir si ataca el acto a través de este contencioso general constitucional o mediante un contencioso especial legal ${ }^{33}$. Si bien la prescripción es un aspecto deficitario de este último ${ }^{34}$, el contencioso especial puede otorgar otras ventajas, como obtener no solo la nulidad, sino la modificación del acto ${ }^{35}$.

30 Sin embargo, el número de acciones contenciosas administrativas sigue siendo incierto. En la década de los ochenta, la doctrina ya contabilizaba cincuenta acciones contenciosas administrativas especiales, véase: Fiamma 1986, 349. Posteriormente, este número se incrementaría significativamente, alcanzando ciento veinte acciones contenciosas administrativas especiales, véase: CARmona 2005, 183 y ss. En general, se acepta que hoy en día este número al menos se duplica.

31 Frente al ejercicio de estas acciones contenciosas especiales, el concepto de prescripción resulta más apropiado que la noción de caducidad, debido a la facultad del interesado de agotar la vía administrativa, y la necesidad de interrumpir el plazo para ejercer la acción contenciosa en caso de preferir dicha vía (art. 54 inc. $2^{\circ}$ de la Ley $N^{\circ} 19.880$, de 2003). Al menos si se considera que "la caducidad se configura dogmáticamente con la existencia de un plazo fatal que no se puede interrumpir ni suspender, por cuanto busca la eficiencia en la actividad administrativa, lo que la distingue de la prescripción": FLORES 2017, 233. Ello parece explicar que el término prescripción sea utilizado por el art. 43 inc. $3^{\circ}$ de Ley $N^{\circ} 19.880$, al señalar que "[e]l abandono no producirá por sí solo la prescripción de las acciones del particular o de la Administración. En todo caso, los procedimientos abandonados no interrumpirán el plazo de prescripción". Por lo demás, este concepto ha sido empleado por la Corte Suprema en sentencias ampliamente comentadas, al concluir que "lo que en realidad prescribe no es la nulidad de derecho público, sino la acción declarativa de derechos a favor del particular" (Droguett con Fisco (2013). No obstante lo anterior, no puede desconocerse que la referencia a la caducidad de acciones es también utilizada por la jurisprudencia, siendo preferida por un sector de la doctrina. La dificultad de explicar este régimen podría justificar que ciertos autores aludan indistintamente a las figuras. V.gr.: VALDIVIA 2018, 245: "Respecto de las acciones judiciales tendientes a la declaración de nulidad, es frecuente que la ley encierre su ejercicio dentro de plazos de prescripción o de caducidad".

32 Bocksang 2012b, 299 y ss.; Sото KLoss 2015, 73 y ss.

33 Brown con Municipalidad de Peumo (1999).

34 HUNTER 2014, 205.

35 Los ejemplos de contenciosos administrativos que permiten esta modificación son variados. En rigor, estos pueden ser tramitados por el juez ordinario. Es el caso del art. 151 letra h) de la Ley N $\mathrm{N}^{\circ}$ 18.695, de 1988, conforme al cual: "La corte, en su sentencia, si da lugar al reclamo, decidirá u ordenará, según sea procedente, la anulación total o parcial del acto impugnado; la dictación de la resolución que corresponda para subsanar la omisión o reemplazar la resolución anulada; la declaración del derecho a los perjuicios, cuando se hubieren solicitado, y el envío de los antecedentes al Ministerio Público, cuando estimare que la infracción pudiere ser constitutiva de delito". No obstante, este modelo ha sido seguido ampliamente por los tribunales especializados en materias administrativas. En el caso del Tribunal de la Contratación Pública, el art. 26 de la Ley N 19.886, de 2003, establece: "En la sentencia definitiva, el Tribunal se pronunciará sobre la legalidad o arbitrariedad del acto u omisión impugnado y ordenará, en su caso, las medidas que sean necesarias para restablecer el imperio del derecho". En el caso de los Tribunales Ambientales, el art. 30 de la Ley N²0.600, de 2012, dispone: "La sentencia que acoja la acción deberá declarar que el acto no es conforme a la normativa vigente y, en su caso, anulará total o parcialmente la disposición o el acto recurrido y dispondrá que se modifique, cuando corresponda, la actuación impugnada". Y, en el caso de los Tribunales Tributarios y Aduaneros, se sigue 
No obstante, condicionado al efecto de cosa juzgada ${ }^{36}$.

En rigor, la facultad de modificar el acto administrativo, propio del ejercicio de ciertos recursos contenciosos, ha sido un aspecto inadvertido por la doctrina. El que estos no solo permitan anular un acto, sino también modificarlo, genera efectos en la interpretación de la superposición. Ella no podrá ser calificada como un "concurso", sino como una mera "yuxtaposición" de recursos, debido a su diversa finalidad. De aquí que el transcurso del tiempo para reclamar la modificación del acto no deba, necesariamente, extinguir el recurso de nulidad general ${ }^{37}$.

La segunda solución al concurso parte de una interpretación diversa, basada en la lectura restrictiva del art. 7 inc. $3^{\circ}$ de la Constitución, cuya operatividad se limitaría a los casos en que el legislador no hubiera consagrado un contencioso especial para atacar el acto de que se trate ${ }^{38}$. En caso contrario, el administrado carecería de un derecho de opción para elegir la vía de ataque ${ }^{39}$. Deberá hacerlo imperativamente por la vía especial, invocando disposiciones legales que contrastan con la acción de nulidad constitucional al presentar una notoria heterogeneidad ${ }^{40}$.

El acceso a la justicia sufre así de variaciones. "[D]esde su denominación (reclamación, apelación, recurso o demanda), la tramitación que debe seguir la demanda (ordinaria, sumaria, proceso de protección, tramitación incidental o sin forma de juicio), los plazos de interposición de ésta $(5,10,15,30$ o 60 días), las reglas probatorias que siguen (ya sea en cuanto al término probatorio, los medios de prueba y la valoración de éstos) y el contenido mismo de

\footnotetext{
una regla similar conforme al art. 156 inc. $3^{\circ}$ del Código Tributario: "El fallo contendrá todas las providencias que el Tribunal juzgue necesarias para restablecer el imperio del derecho y asegurar la debida protección del solicitante, sin perjuicio de los demás derechos que pueda hacer valer ante la autoridad o los tribunales correspondientes". Estas fórmulas no son anecdóticas. Así, en el recurso de protección, la Corte respectiva "adoptará de inmediato las providencias que juzgue necesarias para restablecer el imperio del derecho y asegurar la debida protección del afectado, sin perjuicio de los demás derechos que pueda hacer valer ante la autoridad o los tribunales correspondientes" (art. 20 de la CPR). No obstante, suele asociarse a acciones acotadas en cuanto al plazo.

36 Tocornal con Municipalidad de Vitacura (2004), véase: CoRdero QuinZACARA 2019.

37 En este caso, el transcurso del tiempo impedirá que el interesado demande la modificación del acto por la vía del recurso contencioso especial. Podrá únicamente demandar su nulidad por la vía del contencioso general. En contra: HUNTER 2014, 206.

38 Comunidad Martínez Sandoval con Fisco (2011), véase: Cordero Quinzacara 2019; Aguas Araucanía con Fisco (2017). A diferencia de la interpretación anterior, basada en la jerarquía de las disposiciones, la Corte Suprema ha fundado esta lectura en la especialidad, aplicando el art. 13 del Código Civil: Díaz Guajardo con Fisco (2011), véase Bocksang 2012a, 263 y ss. En fin, esta posición ha sido también afirmada frente a la creación de tribunales especiales: Santa Victoria con Servicios de Impuestos Internos (2012); Comercial y Pesquera Anamar con Servicios de Impuestos Internos (2013), véase: RuIz 2019, 3 y ss. No obstante, se ha sostenido una lectura contraria: Comercial AMS con Servicio de Impuesto Internos (2013), véase: RuIz 2014, 285 y ss.

39 FerRAda 2011, 274-275.

40 HUNTER 2014, 205.
} 
la sentencia (anulatoria, condenatoria o reparatoria), denotan una pluralidad y heterogeneidad difícilmente sistematizable"41.

El principal cuestionamiento afecta al plazo para recurrir. Debido a que este tiempo es consagrado en legislaciones especiales, la preferencia por la imperatividad del recurso contencioso especial impedirá que el administrado pueda atacar el acto por la vía general, una vez transcurrido el plazo. Esta crítica es el principal aspecto que favorece la actualidad del recurso general de nulidad, pues en principio solo éste permite extender los efectos del tiempo. No obstante, dicha situación es más aparente que real, debido a la forma en que opera el control del acto.

\section{b) La imprescriptibilidad de la excepción}

La nulidad suele ser asociada a una acción. La simple denominación de su régimen lo demuestra. En general, los autores nacionales han calificado alternativamente esta institución como una "nulidad de derecho público", una "acción de nulidad de derecho público" o a una "acción constitucional de derecho público"42. No obstante, si la nulidad puede reclamarse a través de una acción, nada impide que pueda serlo por la vía de excepciones o defensas $^{43}$. De hecho, esta asociación se infiere de la posición inicial de la doctrina en la reconstrucción del régimen ${ }^{44}$.

Implícitamente, la aceptación de la excepción de nulidad de derecho público se observa en sentencias ya comentadas. Es lo que ocurre en la Sentencia de Corte Suprema Droguett con Fisco (2013), al afirmar que: "lo que en realidad prescribe no es la nulidad de derecho público, sino la acción declarativa de derechos a favor del particular"45. Cierto, el máximo tribunal alude directamente a la acción no declarativa de derechos, afirmada ya en su sentencia Aedo con Fisco (2000) ${ }^{46}$. No obstante, indirectamente, esta posición es extensible a todo medio diverso a la acción ${ }^{47}$.

\footnotetext{
41 Ferrada 2011, 266.

42 Agüero San Juan 2017, 252. Esto parece obedecer al esfuerzo por deducir el derecho a la acción de nulidad, lo que llevaría a asimilar instituciones en rigor diversas. Véase: FIAmma 1986, 347: "si la nulidad para que se produzca requiere ser declarada, declaración que corresponde precisamente al juez, la vía lógica para transportar a los tribunales la nulidad a que se refiere el precepto citado es el derecho a la acción y de este acoplamiento nace la acción constitucional de nulidad. Sin derecho a la acción el artículo $7^{\circ}$ es simplemente un monumento en homenaje al principio de legalidad, pero jurídicamente inútil".

43 Una tercera alternativa corresponde a la excepción de ilegalidad, susceptible de articularse con un recurso contencioso administrativo. En nuestro Derecho administrativo, esta figura ha sido propuesta por la doctrina, véase: VALDIVIA 2018, 244.

44 Soto Kloss, citado en: Pierry 1993-1994, 86.

45 C. $11^{\circ}$. Véase también: Gardilcic Harasic con Fisco y Empresa de Servicios Sanitarios de Tarapacá (2013).

${ }^{46}$ La acción declarativa referida debe interpretarse en el contexto de la distinción de acciones de nulidad, inaugurada por la Sentencia de Corte Suprema Aedo con Fisco (2000). Véase: Eyzaguirre Cid con Fisco (2007) y Le Roy Barría con Esval SA (2009).

47 De no interponerse dicha excepción o defensa, ni ejercerse la acción respectiva, cabe preguntarse si el juez puede prescindir del acto ilegal. La aplicación del régimen de nulidad absoluta,
} 
Una objeción a ello podrá fundarse en la Ley $N^{\circ} 19.880$, pues, a partir de ésta, "[l]os actos administrativos gozan de una presunción de legalidad, de imperio y exigibilidad" (art. 3 inc. final), imponiendo que el administrado (y no la Administración) recurra al juez, a través de una reclamación directa en contra del acto. Esto, sin embargo, no implica toda ineficacia de las excepciones o defensas, si se considera que un sector de la doctrina ha demostrado los límites de la eficacia que esta disposición puede tener en ciertos supuestos $^{48}$, lo que ha encontrado apoyo en la jurisprudencia reciente del Tribunal Constitucional (v.gr.: en materia de sanciones) ${ }^{49}$.

La primera hipótesis será entonces que la Administración se dirija en contra del administrado, ejerciendo una pretensión declarativa, por la falta de operatividad de la presunción de legalidad. Este supuesto impedirá aplicar los plazos para "recurrir" en contra del acto, al estructurarse en torno a una acción que debe ejercerse por el administrado. Si en la especie es la Administración la que inicia el proceso (para obtener la declaración de legalidad), ninguno de estos plazos resultará aplicable al interesado, que deberá impugnar dicho acto por la vía de excepciones o defensas ${ }^{50}$, siendo el retardo de la Administración lo que justifica la imprescriptibilidad de su ejercicio.

Teóricamente, por tanto, tales plazos de prescripción solo podrían relacionarse con los vicios invalidantes que pudieron afectar a otros actos administrativos previos (dotados de una presunción de legalidad). Este escenario no es excepcional y está presente en general en la medida que la Administración dicte diferentes actos dotados de algún grado de conexión ${ }^{51}$. El ejemplo tradicional consiste en un acto de aplicación de un reglamento ${ }^{52}$ (que es

ampliamente debatido por un sector de la doctrina, permite contribuir a este efecto. A diferencia de la nulidad de derecho público, la nulidad de derecho privado consagra una disposición expresa referida a esta obligación. Es el caso del art. 1683 del Código Civil, que le impone el juez el deber de declarar la nulidad absoluta si aparece de manifiesto en el acto o contrato. No obstante, debe destacarse el carácter marginal de la nulidad absoluta en la materia, aceptada respecto de los vicios de fondo. En contra de esta tendencia: Teitelboim con Fisco (1991).

48 ENTEICHE 2014, 137 y ss.; Sin perjuicio de la doctrina contraria a este régimen de presunciones. Véase: Soto KLoss 2012, 337.

49 Véase las Sentencias del TC Rol N¹518-19 (2009), c. $8^{\circ}$ y Rol N 5.540-18 (2018), c. $63^{\circ}$.

50 En contra: VALDIVIA 2018, 213. Si bien el autor acoge la imprescriptibilidad en relación con los reglamentos, solo admite el carácter imprescriptible del mecanismo en contra de ciertos actos administrativos individuales. Tal es la solución del derecho francés.

51 Véase: VALDIVIA 2009, 876.

52 En el derecho nacional, este mecanismo de inaplicación ha sido conocido en el "contexto de la debilidad histórica del sistema chileno de control jurisdiccional de los actos de la administración": HumERES 2017, 170. El mismo resultado puede alcanzarse a través de la confrontación del acto administrativo con la ley, sin intermediación del reglamento. Pese a que en este caso el examen del reglamento se muestra insuficiente, permite controlar el acto administrativo, pese a no ser interpretado como un acto de aplicación. Véase: PARODI 2005, 45 y ss. El autor destaca que este efecto puede alcanzarse por la vía de la acción de protección (art. 20 de la CPR), al ser integrados bajo la ilegalidad -a propósito de la Sentencia de Corte de Apelaciones de Santiago, Aguas los Dominicos con Superintendencia de Servicios Sanitarios (2005), y de la Sentencia de Corte Suprema Aguas Cordillera con Superintendencia de Servicios Sanitarios (2005)-. No obstante, el mecanismo se muestra insuficiente si de lo que se trata es de demostrar la vulneración 
conocido por un sector de la doctrina en el derecho nacional como el acto administrativo en sentido estricto) $)^{53}$.

En la práctica, sin embargo, este efecto puede resultar limitado; particularmente en relación con el acto reglamentario. Una vez que el juez declare la ilegalidad de su acto de aplicación, la Administración podrá encontrarse sujeta a la obligación de invalidar el reglamento ${ }^{54}$. Esta es la lectura que se desprende de la invalidación, calificada como un poder-deber, sin perjuicio de los términos legales ${ }^{55}$. Si el plazo de dos años de invalidación ${ }^{56}$ ya hubiere transcurrido, la Administración deberá subsanar los vicios del reglamento, conforme al art. 13 inc. final de la Ley $\mathrm{N}^{0} 19.880^{57}$.

Eventualmente, este efecto podría producirse a partir de la anulación del rechazo a una solicitud de invalidación. No obstante, la interpretación estricta del art. 53 de la Ley $N^{\circ}$ 19.880, por parte de la jurisprudencia, ha limitado esta posibilidad, al calificar la inimpugnabilidad del acto que rechaza tal solicitud ${ }^{58}$. Esta lectura ya ha sido objeto de una atenuación por la Corte Suprema ${ }^{59}$. Esta atenuación, pese a su carácter conservador, se inserta en un movimiento favorable a la impugnación de todo acto administrativo, lo que permite prever una futura extensión.

La segunda hipótesis será que la Administración se dirija en contra del administrado, ejerciendo una pretensión ejecutiva, debido a la falta de ope-

del reglamento por parte del acto administrativo de aplicación -sujeto a la obligación de inderogabilidad: Dictámenes № 22.321 (2008) y Nº 60.691 (2014)-. En derecho francés, la excepción de ilegalidad es ampliamente utilizada -Broyelle 2018, 111; GAUDEMET 2015, 136-, al menos si el reglamento ha servido de base a su dictación de un acto administrativo posterior (que es aquel que será impugnado), o si este último se limita a aplicar tal reglamento.

53 Véase: Cordero QuinzaCARA 2010, 25-26. Una posición diversa es afirmada por: PierRY 2005, 71 y ss.

${ }^{54}$ Respecto de la invalidación del reglamento, véase: Dictamen N ${ }^{\circ} 53.290$ (2004); Dictamen No 53.875 (2009); Dictamen No 39.979 (2010).

55 CARRASCO 2012, 75: "El artículo emplea la expresión 'podrá', lo que pudiera dar motivo para entender que se trata de una atribución meramente discrecional. Sin embargo, dicha norma debe ser relacionada con el artículo 58, letra a) del Estatuto Administrativo"; LARA y GUeRRERO 2011, 22; FloRES 2016, 195-196. Véase asimismo, entre otros: Dictámenes No 3.441 (2008) y $N^{\circ} 56.880$ (2011). No obstante, la competencia de apreciación de la ilegalidad ha sido interpretada bajo un carácter exclusivo de la misma autoridad que dicta el acto administrativo, no pudiendo ordenar su invalidación directamente la Contraloría: Sentencia de Corte Suprema Inmobiliaria Punta Piqueros con Contraloría Regional de Valparaíso (2016).

56 Art. 53 de la Ley $N^{\circ} 19.880$, de 2003. Interpretar que el plazo de dos años impide invalidar un reglamento supone aplicar integralmente esta ley a dicha fuente. La doctrina ya ha afirmado la dificultad que ello conlleva, respecto del Capítulo IV sobre la revisión de los actos administrativos. Véase: PierRY 2005, 71 y ss. En un sentido similar: Dictamen No 39.979 (2010).

57 Conforme al art. 13 de la Ley No 19.880: "La Administración podrá subsanar los vicios de que adolezcan los actos que emita, siempre que con ello no se afectaren intereses de terceros". El término "podrá", en este caso, no necesariamente es indicativo de una competencia discrecional, pudiendo suponer un deber de subsanar el acto, similar a lo que ocurre en la invalidación.

${ }^{58}$ CGX Castilla con Seremi de Salud de Copiapó (2010); Castillo Pitripan con Servicio de Evaluación Ambiental (2015).

${ }^{59}$ Comité de Defensa del Patrimonio Histórico y Cultural de Viña del Mar con Municipalidad de Concón (2019). 
ratividad de sus facultades de imperio y ejecución ${ }^{60}$, situación coherente con múltiples disposiciones en aparente contradicción con la interpretación literal del art. 3 inc. final de la Ley $N^{\circ} 19.880^{61}$. Como se verá, la alegación de ciertas excepciones o defensas en tal caso aparece limitada por una jurisprudencia que distingue entre la impugnación de los actos y de sus ejecuciones. Al ser una forma de actuación administrativa, no obstante, ello deberá analizarse junto a otras técnicas favorables a su impugnación.

\section{Las técnicas favorables a la impugnación de la actuación adminis- trativa}

La impugnación de la actuación administrativa no aparece expresamente descrita en la Ley $N^{\circ}$ 19.880, Bases de los Procedimientos Administrativos y, más aún, una lectura apresurada permitiría interpretar su inimpugnabilidad. Así se desprende de la noción legal de acto administrativo, referido por la ley como las "decisiones escritas" que adopte la Administración en ejercicio de sus competencias. Esta definición, concordante con los actos, no se encuentra siempre presente frente a comportamientos pasivos, y solo en ciertos casos preexiste a aquellos activos ${ }^{62}$.

Sin embargo, la impugnación administrativa no solo comprende los actos sino también las actuaciones. Estas últimas pueden ser variadas y adoptar formas que ninguna relación tienen con una decisión escrita de la Administración. La multiplicidad de formas de actuación administrativa puede responder a omisiones (1) y ejecuciones (2) de actos. En un caso y otro, diferentes recursos permiten abrir el contencioso administrativo, superando así la configuración "revisora"63 de actos que, por regla general, tiene la jurisdicción destinada a su control.

\section{La impugnación de la omisión}

Pese a su consagración en ciertos contenciosos administrativos, la noción de omisión no es fácilmente identificable en el Derecho administrativo. La omisión supone la carencia de ejercicio de un deber administrativo. Sin embargo, este deber no siempre se encuentra descrito en términos específicos ${ }^{64}$. La ausencia de especificidad del deber administrativo en ocasiones permite asimilarlo a una competencia discrecional. No obstante ello, ésta puede variar en un sentido reglado, mediante la fabricación de un acto desfavorable (a), susceptible de ser anulado (b).

\footnotetext{
60 ENTEICHE 2014, 143: "pareciendo indisolublemente concatenado a la imperatividad y exigibilidad, la Ley N 19.880 autoriza a que la Administración del Estado ejecute o ponga en práctica de oficio y de modo forzoso, los actos que ya emitió".

61 lbíd., 137 y ss.

62 A favor de una interpretación amplia del acto administrativo, que integra también aquellos verbales y gestuales: MORAGA, 2010, 137 y ss.

63 Nieto 1962, 75 y ss.

64 Pierry 1977, 169; Román 2005, 402 y ss.
} 


\section{a) La fabricación del rechazo implícito}

Salvo excepciones, como en el recurso de protección, la regla general en nuestro país supone el carácter "revisor" del contencioso. Así se deriva de la acción de nulidad de derecho público, que requiere de un "acto" contrario a la legalidad ${ }^{65}$. Este esquema, que es compartido por múltiples contenciosos administrativos especiales, supone interrogarse sobre qué mecanismos emplear en supuestos donde el recurso carece de referencias a hipótesis de inactividad, o bien, cuando la inactividad en sí misma no puede determinarse claramente, pese a integrarse en el recurso.

La respuesta de la doctrina en este escenario supone una primera fase, destinada a crear el acto administrativo ${ }^{66}$. La creación de este acto es posible a partir de la entrada en vigor de la Ley $N^{\circ} 19.880$, que innova en los efectos del silencio administrativo. La regla del silencio positivo permitirá cubrir un amplio espectro de conductas, en las cuales la inactividad de la Administración tendrá como resultado la dictación de un acto favorable, por el solo retardo en su emisión. En otros casos, sin embargo, esta regla se invierte, entendiéndose que el silencio vale rechazo ${ }^{67}$.

El efecto del silencio como rechazo permite constatar un ámbito de aplicación extendido, susceptible de cubrir la mayor parte de los supuestos en los cuales el retardo de la Administración es susceptible de causar una lesión a los derechos del administrado. Basta constatar los términos de la ley del procedimiento administrativo, que comprende, entre otras hipótesis, el ejercicio del derecho de petición (art. $19 \mathrm{~N}^{\circ} 14$ de la CPR) o cualquier solicitud que afecte al patrimonio fiscal ${ }^{68}$. El silencio como rechazo no es sin embargo intrascendente para el control.

En efecto, transcurridos seis meses desde el inicio del procedimiento administrativo ${ }^{69}$, el silencio-rechazo será apto para provocar un acto administrativo implícito desfavorable a la solicitud. Este acto administrativo implícito resulta funcional al carácter de revisor del juez de la Administración en el derecho nacional, bajo supuestos en que ninguna acción contra la omisión sea consagrada por la ley, o bien en hipótesis en las cuales su ejercicio ya no fuera posible. El administrado podrá entonces dirigirse en contra de ella, para efectos de abrir el contencioso.

\footnotetext{
65 Arts. 6 y 7 de la Constitución. En particular, el art. 7 inc. $3^{\circ}$ de la Constitución requiere de un "acto" (sin alusión a una omisión).

66 Nieto 1962, 75 y ss.

67 Arts. 64 y 65 de la Ley $N^{\circ} 19.880$, de 2003.

68 Art. 65 de la Ley $N^{\circ} 19.880$, de 2003. Conforme a esta disposición, lo mismo ocurre en supuestos en los cuales "la Administración actúe de oficio" o, "cuando deba pronunciarse sobre impugnaciones o revisiones de actos administrativos".

69 Art. 27 de la Ley $N^{\circ} 19.880$, de 2003. Vergara 2017, 79 y ss.
} 


\section{b) La anulación del rechazo implícito}

Anular el rechazo implícito supone constatar la ilegalidad de la omisión de la Administración, en casos donde sus condiciones de intervención no aparecen determinadas previamente. La Administración se limita primero a omitir intervenir en un ámbito determinado. Y posteriormente guarda silencio frente a una solicitud destinada a poner término a su inactividad. El juez deberá controlar un aspecto y otro, pudiendo llegar a un resultado desfavorable a la omisión. Si tal es el caso, éste deberá anular el rechazo implícito de intervención.

En rigor, la anulación de un rechazo implícito de intervención equivale a una condena de actuación ${ }^{70}$. Pese al carácter negativo de la nulidad, este es el efecto que produce la acción en este caso. El juez anula el silencio negativo de la Administración, constatando con ello su ilegalidad. Si este silencio es ilegal, es porque la Administración deberá intervenir positivamente. El efecto de la acción no permite la substitución directa de la Administración si ella nada ha resuelto. No obstante ello, le impone a ésta una obligación de abandonar su inactividad.

Diferentes recursos podrían permitir el ejercicio de esta condena administrativa. Y frente a la ausencia de reclamaciones especiales, no parece posible descartar la utilidad del recurso general de nulidad ${ }^{71}$. Esto es particularmente útil en casos donde el recurso de protección vía omisión no es procedente, por las diferencias que presenta este último, en el entendido que él no solo comprende un contencioso objetivo (como es el caso de la nulidad constitucional), sino también un contencioso subjetivo (pues supone la amenaza, privación o perturbación de ciertas garantías) $)^{72}$.

La condena de actuación podrá traducirse en la dictación de actos o en el ejercicio de actuaciones. Por ello, podrá tener lugar un supuesto de actividad formal o material. En ambos casos, se tratará de una limitación a la competencia discrecional que inicialmente la Administración podía ostentar, debiendo entenderse que ella se sujeta a una competencia reglada, que impone una obligación de intervenir, a partir de la anulación del rechazo. Una obligación en tal sentido podrá ser más o menos precisa, pero siempre exigible por parte del interesado.

Lo anterior no solo se relaciona con la distinción entre la faz activa y pasiva de la intervención administrativa, sino también con el carácter funcional de sus competencias ${ }^{73}$. La competencia es un poder-deber, y así lo demuestra el tránsito de una atribución discrecional (basada en la elección válida de actuar $u$ omitir ${ }^{74}$ ) a otra reglada, donde la Administración carecerá de margen de apreciación. Cualquier competencia, por discrecional que sea, es suscep-

\footnotetext{
70 Nieto 1962, 75 y ss.; Nieto 1986, 11 y ss.; Peñalver I Cabré 2013, 149 y ss.

71 Arts. 6 y 7 de la Constitución.

72 Ferrada 2011, 275.

73 Gómez 2011, 101 y ss.; Román 2005, 411.

74 García de Enterría y Fernández 2017, 500.
} 
tible de sujetarse a esta técnica frente a la inactividad, e incluso, si esta actividad, pese a ser desarrollada, adolece de carencias.

\section{La impugnación de la ejecución}

En fin, un último supuesto de aparente inimpugnabilidad administrativa se relaciona con las actuaciones positivas. Al dictar un acto administrativo, la Administración goza de diferentes prerrogativas. Una consiste en el valor legal presunto del acto, mientras que otra se asocia a su ejecución (art. 3 inc. final de la Ley $N^{\circ}$ 19.880, Bases de los Procedimientos Administrativos). La competencia de ejecución por parte de la Administración permite diferenciar dicha fase de la etapa de dictación del acto. Como se verá, la separabilidad de los vicios de estas etapas así lo requiere.

Es por ello que no solo las omisiones pueden ser impugnadas, sino también las ejecuciones. La impugnación de la ejecución del acto administrativo no se confunde con la impugnación del acto considerado en sí mismo, en la medida que se trata de un ataque posterior a su dictación. La jurisprudencia ha considerado esta alternativa de ataque a través de diferentes vías. Una corresponde al decaimiento de la ejecución del acto ya dictado (a). Otra corresponde a la impugnación del vicio que afecta a la actuación material por no encuadrarse en el acto preexistente (b).

\section{a) El decaimiento de la ejecución}

Si el procedimiento administrativo se asocia a la finalidad de producir un acto administrativo terminal, resulta lógico que su ejecución no pueda ser en rigor calificable como tal. En efecto, frente a la ejecución el acto terminal ya ha sido dictado $y$, eventualmente, atacado por parte del administrado. Paralelamente, la ejecución en sí misma es una actividad material de la Administración, alejándose por tanto del procedimiento en un sentido estricto. La ejecución no es un procedimiento ni un acto, sino una actuación, esto es, una actividad material desplegada.

Sin embargo, la distinción entre el acto, el procedimiento y las actuaciones tiene poco sentido desde el punto de vista de la ejecución. Si toda la actividad de la Administración (formal y material) se sujeta a la legalidad, será necesario controlar su contenido. Este control no solamente deberá operar si la Administración efectivamente actúa, sino también si retarda la ejecución de un acto dictado, con independencia de su contenido ${ }^{75}$. Podrá tratarse así

\footnotetext{
75 Vergara 2017, 85: "En la búsqueda de un criterio eficaz para evitar que la administración siga excediendo de modo crónico el "plazo legal" para resolver en los procedimientos administrativos de oficio, la Corte Suprema inició (...) una línea jurisprudencial (...) en que utiliza como solución para la dilación excesiva tanto la figura del decaimiento como el criterio de la inexistencia de plazos fatales para la administración (con diversas disidencias y prevenciones de algunos ministros, en todo caso)". Esta solución ha sido criticada por los autores, debido a la inaplicación del art. 27 de la Ley $N^{\circ}$ 19.880, de 2003, referida a un plazo máximo de seis meses, a favor de la regla de dos años prevista para la invalidación administrativa (art. 53). Véase entre otros: VERGARA 2017, 79 y ss.; Bocksang 2010, 229 y ss.; Cordero Vega 2011b, 243 y ss. Sin embargo, no aparece
} 
de un acto de contenido favorable, pero también desfavorable, como es el caso en materia de sanciones.

Frente a un acto favorable, la Administración podrá encontrarse sujeta a una obligación de hacer. Esta será la consecuencia del acto que preside la actuación, el cual impone al órgano concretar su contenido. Toda carencia de la Administración en la aplicación material de sus efectos supondrá una omisión antijurídica en el plano de la legalidad, pero también un supuesto de una falta de servicio ${ }^{76}$, al constatarse que la Administración no actúa o lo hace tardíamente. El administrado podrá por tanto atacar la inejecución mediante un contencioso objetivo o subjetivo.

Sin embargo, algo distinto sucede respecto de actos de contenido desfavorable. Habitualmente el administrado no tendrá interés en que la ejecución sea efectuada por la Administración, quien puede igualmente retardar ejecutar el acto de gravamen dictado por ella. Este retardo es particularmente perjudicial, considerando que en tal supuesto el plazo de tramitación puede ser respetado por la Administración y, sin embargo, sorprender la confianza del interesado posteriormente, considerando la ausencia de todo plazo en la Ley $N^{\circ} 19.880$, referido a este aspecto.

En efecto, si el procedimiento ha finalizado, no podrá afirmare ya su decaimiento (de dos años) ${ }^{77}$ ni el incumplimiento del deber de tramitación (de seis meses $)^{78}$. Deberá, en cambio, aplicarse una regla de extinción diversa. Aunque recientemente la prescripción de cinco años ${ }^{79}$ ha sido afirmada frente a sanciones ${ }^{80}$, la prescripción de tres años de la acción ejecutiva resulta más acorde al imperio y exigibilidad del acto administrativo ${ }^{81}$. Por lo demás, cabe preguntarse si la prescripción de seis meses ha sido reconsiderada respecto de actos desfavorables no sancionadores ${ }^{82}$.

como aplicable a supuestos en los cuales la Administración dicta el acto terminal, incurriendo posteriormente en una carencia, debido al retardo en la ejecución de la decisión adoptada. En tal caso, ya no existiría un procedimiento, a la luz de los términos del art. 18 de la Ley $N^{\circ} 19.880$, referidos a la producción del acto terminal.

76 Se tratará, por cierto, de una falta de servicio en un sentido subjetivo. Véase: BeRmúdez 2011, 505. Sin embargo, será también una falta de servicio objetiva, asimilada por un sector de la doctrina a la omisión del mismo. Véase: Sото KLoss 2012, 845.

77 Shell Chile S.A. con Superintendencia de Electricidad y Combustibles (2009).

78 Art. 27 de la Ley N 19.880, de 2003.

79 Dictamen N 24.731 (2019). Esta lectura se funda en la consolidación de una posición iniciada ya hace años: Empresa Eléctrica de Aysén con Superintendencia de Electricidad y Combustible (2009); Casino de Juego de Temuco con Superintendencia de Casinos de Juegos (2018); Laboratorios Laffi con Instituto de Salud Pública (2018). Otra interpretación ha sido favorable a la aplicación del art. 94 del Código Penal, que consagra la prescripción de seis meses en materia de faltas. Véase: Cordero QuinzaCARA 2014, 267-270. De hecho, esta última interpretación ha sido tradicional y mayoritaria en este ámbito. Véase: VALLEJo 2016, 287.

80 BeRMúdez 1998, 323 y ss.

81 Art. 2515 del Código Civil. En tal caso, debiera interpretarse que este plazo no admite una conversión de dos años, luego de su término.

82 Debido a que la jurisprudencia administrativa ha reconsiderado el plazo de prescripción de sanciones en sentido estricto ( $y$, más concretamente, de la infracción cometida) -Dictamen 


\section{b) La juridicidad de la ejecución}

Una última alternativa consiste en que la ejecución, producto de una actuación, no se ajuste al contenido del acto preexistente a ella, que justifica la intervención material de la Administración. La Ley $N^{\circ}$ 19.880, Bases de los Procedimientos Administrativos, consagra diferentes mecanismos que permiten el control de esta fase. Primero, al establecer que la ejecutoriedad del acto se condiciona por su notificación o publicación. Y segundo, al consagrar como un deber del órgano que ordena la ejecución, notificar al particular interesado (arts. 50 y 51).

La publicidad del acto administrativo es así el primer elemento de control de la fase de ejecución, al permitir que el administrado tome conocimiento del contenido de la actuación que se desarrollará. Ello ha sido considerado principalmente respecto de los reglamentos, al interpretarse la insaneabilidad de la ausencia de publicación, no solo de su dictación, sino también de su modificación ${ }^{83}$. Algo similar ha ocurrido respecto de actos que miran el interés general, ámbito en que la falta de publicidad ha impedido iniciar el cómputo del plazo de impugnación ${ }^{84}$.

Ahora bien, la impugnación de la fase ejecutiva no se asimila a aquella dirigida en contra del acto terminal del procedimiento administrativo tramitado, debido a que no es posible atacar la ejecución del acto en razón de los vicios que pudieren afectar a este último. Así ha sido afirmado por la Corte Suprema al considerar la separabilidad de los vicios de que pudiere adolecer el acto respecto de aquellos que afectan a la actuación posterior -Sánchez Díaz de Essar S.A. con Municipalidad de Temuco (2010)-, para impedir la apertura de una nueva fase impugnatoria ${ }^{85}$.

El cierre de la impugnación del acto, una vez que éste se encuentre en estado de ejecución, se basa por tanto en la seguridad. Sin embargo, la aplicación irrestricta de esta separación resulta criticable. Por regla general el control del acto se encuentra relacionado con el contenido de su ejecución. Esto, ya que la Administración no es libre de ejecutar el acto de cualquier modo, sino solo atendiendo a su contenido. Una ejecución contraria no solo

$N^{\circ} 24.731$ (2019)-, no parece afectarse la jurisprudencia anterior, aplicable respecto de actos desfavorables no sancionadores. Por otro lado, ya que el plazo del art. 2515 del Código Civil supera el doble del tiempo necesario para hacer decaer el procedimiento administrativo, conforme a la jurisprudencia, cabe preguntarse si la prescripción del art. 94 del Código Penal, de seis meses en materia de faltas (y no el Código Civil), consagra los principios de general aplicación en este ámbito. Al respecto, pero en relación con el Código Civil: Ferrada 2007, 117.

83 Hernández con Municipalidad de Lago Ranco (2013).

84 Ossandón con Municipalidad de Concón (2013).

85 En la sentencia en cuestión la Corte concluye: "aceptar la impugnabilidad del acto de ejecución por medio del reclamo de ilegalidad importaría que en la medida que el acto de conclusión no fuere atacado, podría dar lugar, indefinidamente, a nuevos procesos contencioso administrativos. Lo expresado en sin perjuicio de la facultad de impugnar un acto administrativo de ejecución afectado por un vicio originado solo a partir de su emisión, cuyo no es el caso" (c. $12^{\circ}$ ). 
permite declarar la ilegalidad de ésta, sino también la del acto, debido a la estrecha relación que existe entre una y otro.

Por un lado, esta relación podrá dar lugar a vicios que afectan al acto administrativo cuya ejecución se pretende. Un ejemplo se aprecia en la desviación de poder. El análisis de esta relación ha sido tradicional en la expropiación ${ }^{86}$, respecto de bienes destinados a un fin diverso del que motivó el acto expropiatorio. Sin embargo, nada impide analizar otros supuestos. Por otro lado, podrá suceder que el acto en sí mismo carezca de vicios y que, sin embargo, deba de todas formas perder su eficacia. El ejemplo tradicional de ello tendrá lugar frente a su decaimiento.

\section{Conclusiones}

1. Si el contencioso administrativo forma parte del principio de legalidad, entonces la eficacia de los recursos contenciosos condicionan el rol del Derecho administrativo en un Estado de Derecho. Tradicionalmente, la eficacia de los recursos jurisdiccionales es limitada por diversas reglas, que limitan la impugnabilidad de los actos y de las actuaciones de la Administración.

2. La impugnación de actos ha sido habitualmente limitada antes y después de la dictación de un acto terminal, que pone fin al procedimiento administrativo. La limitación anterior se relaciona con la inimpugnabilidad de los actos trámites. Aquella posterior, se asocia a las restricciones impuestas a la impugnación del acto terminal, una vez transcurrido el plazo para accionar.

3. Diferentes técnicas permiten superar estas restricciones. Respecto del acto trámite, la apertura de la impugnación se relaciona con la reposición administrativa y el recurso de protección. Respecto del terminal, la apertura indirecta del contencioso se asocia a la vigencia del mecanismo de excepción en el proceso administrativo, al permitir extender la impugnación del acto.

4. La impugnación de las actuaciones posee también limitaciones aparentes. Frente a las carencias, se asocian a la dificultad de determinar un supuesto de omisión ilegal, pero también a la configuración general de los recursos (que no siempre consagran una hipótesis omisiva). Frente a las ejecuciones, ya que la impugnación de la ejecución no se confunde con el ataque del acto.

5. Las técnicas contenciosas permiten también comprender estos supuestos. Respecto de las omisiones, ya que la nulidad de una decisión desfavorable a intervenir equivale a una condena de actuación. Respecto de las ejecuciones, debido a que la Administración no es libre para determinar su oportunidad, ni menos aún su contenido, debiendo sujetarse al acto que la precede.

\footnotetext{
86 Bajo la figura de la retrocesión, si la Administración destina el bien a una finalidad distinta a la expresada en el decreto de expropiación. Torres con Fisco (2004). Véase: Bermúdez 2011, 476.
} 


\section{Bibliografía citada}

Agüero San Juan, Claudio (2017). Cuatro versiones de la Nulidad de Derecho Público. Primera parte: La versión de Mario Bernaschina González. Revista lus et Praxis, Vol. 23, $N^{\circ} 2$, pp. 251-294.

BermúdEZ, Jorge (1998). Elementos para definir las sanciones administrativas. Revista Chilena de Derecho, Vol. 25, N 1, pp. 323-334.

Bermúdez, Jorge (2008). El principio de legalidad y la nulidad de derecho público en la constitución política - Fundamentos para la aplicación de una solución de derecho común. Revista de Derecho Público, Nº 70, pp. 273-285.

Bermúdez, Jorge (2010). Estado actual del control de legalidad de los actos administrativos: ¿Qué queda de la nulidad de derecho público? Revista de derecho (Valdivia), Vol. 23, $\mathrm{N}^{\circ} 1$, pp. 103-123.

Bermúdez, Jorge (2011). Derecho administrativo general. Santiago, Legalpublishing, $2^{\mathrm{a}}$ Edición, 602 pp.

BocksANG, Gabriel (2010). La dilación excesiva de los procedimientos administrativos sancionatorios: A horcajadas entre decaimiento y nulidad. Sentencias Destacadas LYD, pp. 225-252.

BockSANG, Gabriel (2012a). Díaz Guajardo con Fisco - Nulidad de derecho público - DL $\mathrm{N}^{\circ} 2695$ de 1979. Ius Publicum, N²8, pp. 263-268.

BocksANG, Gabriel (2012b). La ampliación de las causales de nulidad de derecho público por la Corte Suprema. Sentencias destacadas LYD, pp. 299-314.

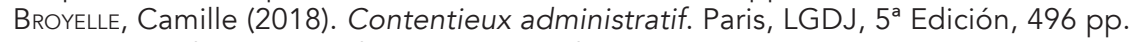

Carmona, Carlos (2005). El contencioso-administrativo entre 1990 y 2003. En: FerradA, Juan Carlos [coord.], La Justicia Administrativa, Santiago, LexisNexis, pp. 183-240.

CARRASCO, Andrés (2012). La invalidación y la revocación de los actos administrativos: Doctrina y jurisprudencia judicial y administrativa. Revista Derecho y Justicia, N², pp. 69-99.

ContARDo, Juan Ignacio (2019). Contrato de transacción contrario al derecho público chileno celebrado por una municipalidad con un funcionario - Procedencia de la nulidad absoluta en desmedro de la nulidad de derecho público - Corte Suprema: Roles $N^{\circ} 15943-2016,24$ de mayo de 2016; No 14333-2016, 19 de mayo de 2016; N 68092016, 19 de mayo de 2016; No 10528, 29 de marzo de 2016; N $N^{\circ}$ 21898-2015, 24 de marzo de 2016; No 17893-2015, 10 de marzo de 2016; N 14276-2014, 30 de octubre de 2014". Revista lus et Praxis, año 25 N¹, pp. 521-536.

Cordero Quinzacara, Eduardo (2010). Las normas administrativas y el sistema de fuentes. Revista de Derecho Universidad Católica del Norte, año 17, N 1, pp. 21-50.

Cordero Quinzacara, Eduardo (2014). Derecho administrativo sancionador. Santiago, Legalpublishing, $302 \mathrm{pp}$.

Cordero Quinzacara, Eduardo (2019). Los reglamentos como fuente del derecho administrativo y su control jurisdiccional. Revista lus et Praxis, Vol. 25, No 1.

Cordero VeGA, Luis (2007). El principio del control público en el derecho administrativo chileno. En: PANTOJA, Rolando [coord.], Derecho administrativo chileno, México, Editorial Porrúa, pp. 591-731.

Cordero VegA, Luis (2011a). Comentario a la sentencia de la Corte Suprema sobre la Central Termoeléctrica Castilla: Un caso de Derecho Administrativo Procedimental. Revista Justicia Ambiental, No3, pp. 192-201.

Cordero VeGA, Luis (2011b). El decaimiento del procedimiento administrativo sancionador: comentarios a las sentencias de la Corte Suprema del año 2010. Anuario de derecho público UDP, N², pp. 243-255.

Delmoste, Marie-France (2001). Les polices administratives spéciales et le principe d'indépendance des législations. Paris, LGDJ, 290 pp.

Enteiche, Nicolás (2014). La excepcional autotutela ejecutiva de los actos administrativos en Chile. Revista de Derecho de la Universidad Católica del Norte, Vol. 21, № 2 , pp. 137-182. 
FERRADA, Juan Carlos (2007). Los principios estructurales del Derecho administrativo chileno - Un análisis comparativo. Revista de Derecho de la Universidad de Concepción, $\mathrm{N}^{\circ}$ 221-222, pp. 99-136.

Ferrada, Juan Carlos (2010). Nuevas restricciones a la nulidad de derecho público como proceso administrativo - Una jurisprudencia interesante, pero inconsistente. Anuario de Derecho Público UDP, № 1, pp. 189-203.

FerRADA, Juan Carlos (2011). Los procesos administrativos en el Derecho chileno. Revista de Derecho de la Pontificia Universidad Católica de Valparaíso, Nº36, pp. 251-277.

FerRadA, Juan Carlos (2013). La legitimación activa en los procedimientos administrativos anulatorios en el derecho chileno. En: Ferrada, Juan Carlos [coord.], IX Jornadas de Derecho administrativo: La nulidad de los actos administrativos en el derecho chileno. Santiago, Thomson Reuters, 582 pp.

Fiamma, Gustavo (1986). La acción constitucional de nulidad: un supremo aporte del constituyente de 1980 al derecho procesal administrativo. Revista de Derecho de la Pontificia Universidad Católica de Valparaíso, № 10, pp. 345-353.

FLORES, Juan Carlos (2016). La potestad revocatoria de los actos administrativos. Revista de Derecho de la Universidad Católica del Norte, N 1, pp. 191-222.

FLORES, Juan Carlos (2017). La caducidad de los actos administrativos. Revista de Derecho (Valdivia), Vol. 30, N², pp. 225-249.

Garcia de EnTerRIA, Eduardo y Fernández, Tomás-Ramón (2017). Curso de Derecho administrativo. Madrid, Thomson Reuters, T I, $871 \mathrm{pp}$.

Gaudemet, Yves (2015). Droit administratif. Paris, LGDJ, 21 a Edición, 544 pp.

Gómez, Marcos (2011). La inactividad de la Administración. España, Aranzadi Ediciones, $4^{\text {a }}$ Edición, 1342 pp.

HUNTER, Iván (2014). Reclamo de ilegalidad municipal en la jurisprudencia: caos interpretativo y criterios dudosos. Revista de derecho (Valdivia), Vol 27, № 2, pp. 191-215.

HUMERES, Nicolás (2017). La potestad reglamentaria y su control judicial: recurso de protección e inaplicación de normas administrativas. Revista de Derecho Administrativo Económico, $\mathrm{N}^{\circ} 24$, pp. 157-179.

JARA, Jaime (2008). La garantía jurídica de la unidad del procedimiento administrativo en la Ley N¹9.880. Revista de Derecho Público, N 70, pp. 287-311.

LARA, José Luis y GuerRero, Gonzalo (2011). Aspectos críticos de la invalidación administrativa en la ley 19.880: análisis en la jurisprudencia de la Contraloría General de la República a 8 años de su vigencia. Revista de Derecho Escuela de Postgrado, № 1, pp. 17-44.

Moraga, Claudio (2010). La actividad formal de la Administración del Estado. En: PANTOJA BAUZA, Rolando [coord.], Tratado de Derecho Administrativo, Santiago, Legalpublishing, Tomo VII, 556 pp.

Nieto, Alejandro (1962). La inactividad de la administración y el recurso contencioso-administrativo. Revista de Administración Pública, №37, pp. 75-126.

Nieto, Alejandro (1986). La inactividad material de la Administración veinticinco años después. Documentación administrativa, № 208, pp. 11-64.

Pantoja, Rolando (2010). El artículo 38 inciso $2^{\circ}$ de la Constitución Política de la República. En: Tavolarl, Raúl [coord.], Doctrinas esenciales - Derecho Constitucional, Santiago, Editorial Jurídica de Chile, pp. 695-714.

PARODI, Alejandro (2005). Tres lecciones acerca de cómo se deben proteger los derechos de las personas frente a la Administración. Sentencias Destacadas LYD, pp. 45-62.

Peñalver I Cabré, Alexandre (2013). Las pretensiones en el contencioso-administrativo para la efectiva protección de los intereses colectivos. Revista de Administración Pública, $\mathrm{N}^{\circ} 190$, pp. 149-194.

PIERRY, Pedro (1977). El recurso de protección y lo contencioso administrativo. Revista de Derecho de la Pontificia Universidad Católica de Valparaíso, N 1, pp. 153-173.

PierRY, Pedro (1993-1994). Nulidad en el Derecho administrativo. Revista de Derecho de la Pontificia Universidad Católica de Valparaíso, Nº 15, pp. 79-100.

PIERRY, Pedro (2000). La responsabilidad extracontractual del Estado por falta de servicio. Revista de Derecho del Consejo de Defensa del Estado, № 1, pp. 11-39. 
Pierry, Pedro (2005). Concepto de acto administrativo en la ley de procedimiento administrativo: el reglamento, dictámenes de la Contraloría General de la República. Revista de Derecho del Consejo de Defensa del Estado, № 13, pp. 71-80.

RoJAs, Christian (2007). Sistema de revisión de los actos administrativos contemplados en la Ley General de Pesca y Acuicultura (a la luz de los estándares de la Ley de Bases de Procedimientos Administrativos). Revista de Derecho Público, Vol. 69, pp. 117-138.

RomÁn, Christian (2005). Inactividad administrativa y responsabilidad del Estado. Revista de Derecho Público, No 67, pp. 402-423.

Ruiz, Germán (2014). Nulidad de derecho público tributaria. Revista de Estudios Públicos Tributarios, No 10 , pp. 285-297.

Ruiz, Germán (2019). Nulidad de derecho público tributaria. En: EQuipo Editorial Thomson Reuters [eds.], Grandes temas de Derecho Tributario - Manual de Consultas Tributarias, Santiago, Thomson Reuters, Vol. I, pp. 326.

Sото Kıoss, Eduardo (1984). El recurso de protección: aspectos fundamentales. Revista Chilena de Derecho, Vol. 11, N²-3, pp. 365-372.

Sото KLoss, Eduardo (2012). Derecho administrativo: temas fundamentales. Santiago, Legalpublishing, $966 \mathrm{pp}$.

Sото KLoss, Eduardo (2015). La nulidad de derecho público hoy: de su tergiversación a su destrucción. Revista lus Publicum, Nº34, pp. 73-92.

VALDIVIA, José Miguel (2009). Sobre la nulidad en Derecho público. En: Flores et al. [coord.], La primacía de la persona humana: Estudios en homenaje al profesor Eduardo Soto Kloss, Santiago, Legalpublishing, pp. 865-885.

VALDIVIA, José Miguel (2018). Manual de Derecho administrativo. Valencia, Tirant lo Blanch, $448 \mathrm{pp}$.

VALDIVIA, José Miguel y BLAKE, Tomás (2015). El decaimiento del procedimiento administrativo sancionatorio ante el derecho administrativo, Estudios Públicos, № 138, pp. 93-135.

VAlLeJo, Rodrigo (2016). Acerca del régimen supletorio de prescripción aplicable a las infracciones y sanciones administrativas. Revista de Derecho de la Pontificia Universidad Católica de Valparaíso, N 47, pp. 281-301.

Vergara, Alejandro (2007). Eficacia derogatoria y supletoria de la Ley de Bases de los Procedimientos Administrativos. En: Escuela de Derecho de la Pontificia Universidad Católica de Valparaíso [ed.], Acto y Procedimiento Administrativo - Actas de las Segundas Jornadas de Derecho Administrativo. Valparaíso, Ediciones Universitarias de Valparaíso, pp. 31-47.

Vergara, Alejandro (2017). El mito de la inexistencia de plazos fatales para la administración y el "decaimiento" en los procedimientos administrativos. Estudios Públicos, № 148, pp. 79-118.

\section{Normas jurídicas citadas}

Código Sanitario, Decreto con Fuerza de Ley No 725 del 31 de enero de 1968, Ministerio de Salud, que fija el texto refundido, coordinado y sistematizado del Código Sanitario. Diario Oficial, 31 enero 1968.

Código Tributario, Decreto Ley No 830 del 31 de diciembre de 1974, Ministerio de Hacienda, que aprueba el Código Tributario. Diario Oficial, 31 diciembre 1974.

Ley No 19.300, Bases Generales del Medio Ambiente. Diario Oficial, 9 marzo 1994.

Decreto con Fuerza de Ley $N^{\circ} 1$ del 30 de mayo de 2000, Ministerio de Justicia, que fija el texto refundido, coordinado y sistematizado del Código Civil.

Decreto con Fuerza de Ley No 1 del 17 de noviembre de 2001, Ministerio Secretaría General de la Presidencia, que fija el texto refundido, coordinado y sistematizado de la Ley 18.575, Orgánica constitucional de Bases Generales de la Administración del Estado. Diario Oficial, 5 diciembre 1986.

Ley $N^{\circ} 19.880$, que establece bases de los procedimientos administrativos que rigen los actos de los órganos de la Administración del Estado. Diario Oficial, 29 mayo 2003. 
Ley $N^{\circ} 19.886$, Bases sobre contratos administrativos de suministro y prestación de servicios. Diario Oficial, 30 julio 2003.

Decreto con Fuerza de Ley $N^{\circ} 1$ del 26 de julio de 2006, Ministerio del Interior, que fija el texto refundido, coordinado y sistematizado de la Ley 18.695, Orgánica constitucional de Municipalidades. Diario Oficial, 31 marzo 1988.

Ley N²0.600, que crea los Tribunales Ambientales. Diario Oficial, 28 junio 2012.

\section{Jurisprudencia citada}

Teitelboim con Fisco (1991): Corte de Apelaciones de Santiago, 5 noviembre 1991.

Pérsico Paris con Fisco (1997): Corte Suprema, 20 noviembre 1997.

Brown con Municipalidad de Peumo (1999): Corte Suprema, 5 octubre 1999.

Aedo con Fisco (2000): Corte Suprema, 27 noviembre 2000.

Aguas los Dominicos con Superintendencia de Servicios Sanitarios (2004): Corte de Apelaciones de Santiago, 24 septiembre 2004.

Torres con Fisco (2004): Corte Suprema, 28 octubre 2004.

Tocornal con Municipalidad de Vitacura (2004): Corte de Apelaciones de Santiago, 15 diciembre 2004.

Aguas Cordillera con Superintendencia de Servicios Sanitarios (2005): Corte Suprema, 19 abril 2005.

Camacho con Fisco (2006): Corte Suprema, 28 junio 2006.

Eyzaguirre Cid con Fisco (2007): Corte Suprema, 28 junio 2007.

Abrego Diamantti con Instituto de Normalización Previsional (2007): Corte Suprema, 29 noviembre 2007.

Le Roy Barría con Esval SA (2009): Corte Suprema, 27 enero 2009.

Empresa Eléctrica de Aysén con Superintendencia de Electricidad y Combustible (2009): Corte Suprema, 15 octubre 2009.

Shell Chile SA con Superintendencia de Electricidad y Combustibles (2009): Corte Suprema, 28 diciembre 2009.

Sánchez Díaz de Essar SA con Municipalidad de Temuco (2010): Corte Suprema, 22 julio 2010.

CGX Castilla con Seremi de Salud de Copiapó (2010): Corte Suprema, 15 noviembre 2010.

Comunidad Martínez Sandoval con Fisco (2011): Corte Suprema, 12 septiembre 2011.

Díaz Guajardo con Fisco (2011): Corte Suprema, 7 noviembre 2011.

Santa Victoria con Servicios de Impuestos Internos (2012): Corte Suprema, 2 enero 2012.

Ovalle Lecaros con Fisco, Servicio Agrícola y Ganadero y Servicio de Vivienda y Urbanismo Metropolitano (2012): Corte Suprema, 1 junio 2012.

Droguett con Fisco (2013): Corte Suprema, 4 enero 2013.

Comercial AMS con Servicio de Impuesto Internos (2013): Corte de Apelaciones de Talca, 4 enero 2013.

Gardilcic Harasic con Fisco y Empresa de Servicios Sanitarios (2013): Corte Suprema, 8 abril 2013.

Ossandón con Municipalidad de Concón (2013): Corte Suprema, 2 mayo 2013.

Hernández con Municipalidad de Lago Ranco (2013): Corte Suprema, 2 septiembre 2013.

Comercial y Pesquera Anamar con Servicios de Impuestos Internos (2013): Corte Suprema, 26 noviembre 2013.

Trucco con Dirección General de Aguas (2015): Corte de Apelaciones de Santiago, 4 marzo 2015.

Castillo Pitripan con Servicio de Evaluación Ambiental (2015): Corte Suprema, 22 abril 2015.

Inmobiliaria Punta Piqueros con Contraloría Regional de Valparaíso (2016): Corte Suprema, 4 octubre 2016.

Aguas Araucanía con Fisco (2017): Corte Suprema, 25 septiembre 2017.

Casino de Juego de Temuco con Superintendencia de Casinos de Juego (2018): Corte Suprema: 8 enero 2018. 
Laboratorios Laffi con Instituto de Salud Pública (2018). 23 octubre 2018.

Comité de Defensa del Patrimonio Histórico y Cultural de Viña del Mar con Municipalidad de Concón (2019): Corte Suprema, 19 noviembre 2019.

Sentencia TC Rol No 1518 (2009): Tribunal Constitucional, 23 octubre 2009.

Sentencia TC Rol No 1849 (2011): Tribunal Constitucional, 12 mayo 2011.

Sentencia TC Rol No 5540 (2018): Tribunal Constitucional, 18 diciembre 2018.

Dictamen N 53.290 (2004): Contraloría General de la República, 25 de octubre de 2004.

Dictamen N 3.441 (2008): Contraloría General de la República, 24 de enero de 2008.

Dictamen N 22.321 (2008): Contraloría General de la República, 13 de mayo de 2008.

Dictamen No 53.875 (2009): Contraloría General de la República, 29 de septiembre de 2009.

Dictamen Nº 56.880 (2011): Contraloría General de la República, 7 de septiembre de 2011.

Dictamen No 60.691 (2014): Contraloría General de la República, 8 de agosto de 2014.

Dictamen No 24.731 (2019): Contraloría General de la República, 12 de septiembre de 2019. 